\title{
The use of wind pumps for greenhouse microirrigation: A case study for tomato in Cuba
}

\author{
Manuel Peillón , Raúl Sánchez ， Ana M. Tarquis ， José L. García-Fernández
}

\begin{abstract}
A B S T R A C T
Crop irrigation is a major consumer of energy. Only a few countries are self-sufficient in conventional nonrenewable energy sources. Fortunately, there are renewable ones, such as wind, which has experienced recent developments in the area of power generation. Wind pumps can play a vital role in irrigation projects in remote farms.

A methodology based on daily estimation balance between water needs and water availability was used to evaluate the feasibility of the most economic windmill irrigation system. For this purpose, several factors were included: three-hourly wind velocity $\left(W_{3 \mathrm{~h}}, \mathrm{~m} / \mathrm{s}\right)$, flow supplied by the wind pump as a function of the elevation height $(H, \mathrm{~m})$ and daily greenhouse evapotranspiration as a function of crop planting date. Monthly volumes of water required for irrigation ( $D r, \mathrm{~m}^{3} / \mathrm{ha}$ ) and in the water tank ( $V d$, $\mathrm{m}^{3}$ ), as well as the monthly irrigable area $(A r, \mathrm{ha})$, were estimated by cumulative deficit water budgeting taking in account these factors.

An example is given illustrating the use of this methodology on tomato crop (Lycopersicon esculentum Mill.) under greenhouse at Ciego de Âvila, Cuba. In this case two different $W_{3 \mathrm{~h}}$ series (average and low wind year), three different $H$ values and five tomato crop planting dates were considered. The results show that the optimum period of wind-pump driven irrigation is with crop plating in November, recommending a $5 \mathrm{~m}^{3}$ volume tank for cultivated areas around 0.2 ha when using wind pumps operating at $15 \mathrm{~m}$ of height elevation.
\end{abstract}

\section{Introduction}

The energy supply is a growing concern to both governments and researchers. The indiscriminate use of oil by modern society has led to energetic, economic and ecological instability worldwide (Baracca, 2007; Corp, 2003). In addition to this energy crisis, the world also faces a food crisis (Vázquez and Montesinos, 2007); therefore, it is of great importance that policies designed to achieve sustainable development take into account both energy and food supply needs. In some countries with a well-known economic isolation situation, such as Cuba, both of these problems have grown. Over $50 \%$ of Cuba's oil imports are destined to provide energy for production processes (Nova, 2007). Indeed, 94\% of the nation's elec-

\footnotetext{
* Corresponding author at: Technical University of Madrid (UPM), Departamento de Ingeniería Rural, Spain. Tel.: +34 913365694; fax: +34 913365845.

E-mail address: raul.sanchez@upm.es (R. Sănchez).
}

tricity production depends on oil (Torres, 2007). The only viable alternative is to make use of renewable energy resources.

In recent years, Cuba's economy has demanded ever larger food imports. In 2007, approximately US $\$ 1.7$ billion was spent on such imports, which represented $18 \%$ of all imported goods. However, a significant proportion of these imported foods could be produced domestically under competitive conditions, especially given the current high price of food in the international market (Nova, 2012).

This situation has led to an interest in developing energy conversion devices to take advantage of renewable energy resources that can reduce dependency on fossil fuels. In this respect, wind energy has been shown to be an economically viable and sustainable energy resource after its energy use footprint was assessed (Proenza et al., 2007).

Knowledge of regional wind availability and behaviour over the course of the year allows users to take advantage of it in a systematic way and aids them in planning use-related activities. Such knowledge also allows the use of wind power to be considered as a means of guaranteeing the energy that is required by drip 


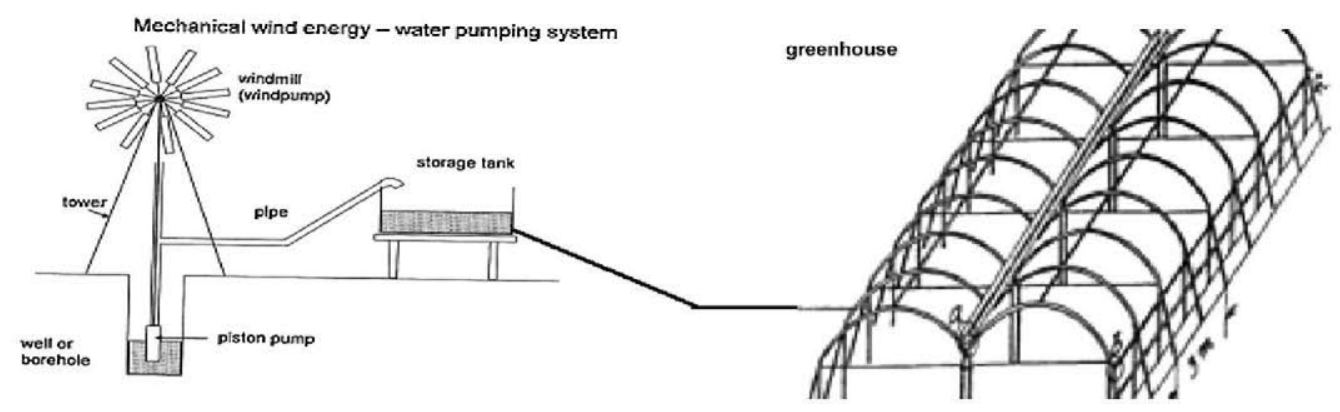

Fig. 1. Installation proposed for the supply of water by wind-pumps.

irrigationprocesses in greenhouses. A greenhouse is a production system that allows crops to be grown inside in circumstances when it would be impossible or uneconomical outdoors. The aim of a greenhouse production system is to keep the most relevant climatic variables between the limits that are demanded by crop physiology in such a way that the final system is profitable (García et al., 1999).

Outdoor vegetable production in Cuba is seasonal and is therefore limited by climatic and agronomic factors. Consequently, current domestic production efforts cannot guarantee that the required quantity and quality of vegetables will be met without imports. The demand for vegetables has already surpassed 6700 t/year (Minagri, 2000) and continues to grow owing to an increase in tourism. Given Cuba's limited financial resources, the scarcity of water on the island, the instability of the diesel supply, and an accelerated deterioration of the nation's irrigation systems, the future of irrigation and drainage seems complicated. However, the country goes to extraordinary lengths to maintain the area that is under irrigation to make better use of water and energy and to increase its agricultural production (González and Mendez, 2004).

Given this scenario, the development of a technology that combines wind pumping and drip irrigation that could allow the sustainable production of greens and vegetables is an attractive option. The energy cost would be decreased and such technology should cause no environmental problems.

The aim of the present work was to design a methodology for analysing the possible use of wind energy for the irrigation of greenhouse tomato (Lycopersicon esculentum Mill. cv. FL-5) crops in Cuba that could be applied to other situations. Additional objectives were the investigation of the necessary capacity of water storage tanks to meet the demand for irrigation under different wind conditions and to determine, with respect to wind availability, the optimum production dates that would allow the maximum possible area to be irrigated in addition to possible irrigation needs at varying levels of risk. The planting date is a factor that was not previously studied in other works that assessed the use of wind energy for irrigation.

The following factors were studied over the course of this investigation: wind velocity $(W, \mathrm{~m} / \mathrm{s})$, elevation height $(H, \mathrm{~m})$, flow supplied by the wind pump $(Q, 1 / \mathrm{min})$, daily greenhouse evapotranspiration $(E T r, \mathrm{~mm})$, irrigation efficiency $(E f)$, monthly volume of water required for irrigation $\left(D r, \mathrm{~m}^{3} / \mathrm{ha}\right)$, monthly volume of water pumped into the tank $\left(V d, \mathrm{~m}^{3}\right)$, and monthly irrigable area $(\mathrm{Ar}, \mathrm{ha})$.

\section{Materials and methods}

\subsection{Installation elements}

The water supply system that is considered in this study is one of the simplest (Fig. 1):

\subsubsection{Wind pump model}

The wind pump was designed as a $6 \mathrm{~m}$-high conical tower with a triangular section. Its rotor was $2.2 \mathrm{~m}$ in diameter with eight blades, and it required a wind velocity of $2.77 \mathrm{~m} / \mathrm{s}$ to start. These characteristics are typical of many commercial models. In the present work, only starting wind velocities higher than $2.77 \mathrm{~m} / \mathrm{s}$ to start up and lower than recommended for security reason $(10.8 \mathrm{~m} / \mathrm{s})$ were considered for the flow extracted by the wind pump for security reasons.

\subsubsection{Water storage tank}

The volume of the water storage tank should guarantee that the water requirements of the crop are met. At the same time, the tank should have an elevation that is high enough to provide enough pressure for local irrigation, and it should be covered to eliminate evaporation. Therefore, the water tank serves as a regulatory element so that irrigation is not affected by changes in wind velocity.

\subsubsection{Greenhouses}

The greenhouses that were selected for this study were the types that are most commonly used in the area. These greenhouses are multi-tunnels with a length of $40 \mathrm{~m}$, a width of $20 \mathrm{~m}$ and a height, at the highest point, of $5 \mathrm{~m}$. The covered area was $800 \mathrm{~m}^{2}$.

\subsection{Wind in the study area}

\subsubsection{Data}

Weather data were collected from weather station 78346 $\left(21^{\circ} 47^{\prime} \mathrm{N}, 78^{\circ} 47^{\prime} \mathrm{W}\right)$, which is located in the town of Venezuela, Province de Ciego de Ávila, Cuba. This weather station automatically recorded the pulses emitted by an anemometer (set at a height of $11 \mathrm{~m}$ ) every minute to determine the mean wind velocity for each minute $\left(W_{1 \mathrm{~min}}\right)$.

Mean wind velocities for each 3-h period $\left(W_{3 h}\right)$ from 1970 until 2008 were recorded monthly and tabulated in wind frequency tables that were classified into 12 wind velocity ranges and 8 time periods. Therefore, each month of each year's data was shown as a table formed by 12 columns, from $0-1$ through $54-66 \mathrm{~km} / \mathrm{h}$, and eight rows, from 00:00-03:00 through 21:00-24:00 h. Only the last year, 2008, shows the original $W_{3 \mathrm{~h}}$ data as a time series.

Wind velocities from 1970 through 2007 were statistically processed to obtain average monthly $W_{3 \mathrm{~h}}$ values, along with monthly $W_{3 \mathrm{~h}}$ frequencies and the average monthly frequencies of $W_{3 \mathrm{~h}}$ during the 8 time intervals. The wind velocity data from 2008 were retained to test the simulation algorithm.

\subsubsection{Wind velocity monthly distribution}

Attempts have been made to fit the field results to the Pearson IV, exponential and gamma distributions (Panda et al., 1990), as well as the logistic distribution (Scerri and Farrugia, 1996). However, the Weibull distribution and its modification the Rayleigh distribution have also been used to study wind data (Stevens and Smulders, 1979; Lun and Lan, 2000), and they are commonly used in modelling studies involving wind energy (Celik, 2003). Sathyajith et al. (2002) 
used the Rayleigh distribution to characterise the wind potential at eight sites in the Kerala area of India to determine the available energy over a period of time, along with the most common wind velocities, and the wind velocity with the maximum usable energy. Corotis et al. (1978) suggested that the Rayleigh distribution might be more useful than the Weibull distribution, but Henneessy (1977) determined that the energy production calculated from wind velocity using the Rayleigh distribution was $10 \%$ of that returned by the Weibull distribution. Rehman et al. (1994) used the Weibull distribution to study wind data from 10 sites in Saudi Arabia and concluded that this approach was adequate. Finally, Atsu (2002) modelled wind data for four seasons in Oman using the Weibull distribution variables. These variables were estimated using the moments, regression and chi-squared methods. The latter provided the best estimates according to the results of Kolmogorov-Smirnov tests.

Histograms of monthly frequencies of $W_{3 \mathrm{~h}}$, based on 1970 till 2007 , were then constructed, adjusting the wind velocity values to the Weibull II distribution function:

$f\left(W_{3 \mathrm{~h}} ; \alpha ; \beta\right)=\frac{\alpha}{\beta^{\alpha}} W_{3 \mathrm{~h}}^{-1} e^{-\left(W_{3 \mathrm{~h}} / \beta\right)} e^{-\left(W_{3 \mathrm{~h}} / \beta\right)^{\alpha}}$

where:

$W_{3 \mathrm{~h}}$ is three hourly wind velocity $(\mathrm{m} / \mathrm{s})$

$\alpha$ is the shape parameter (adimensional)

$\beta$ is the scale parameter (which has wind velocity units)

$f$ is the relative frequency at the specified three hourly wind velocity

Both parameters were estimated ( $\alpha$ and $\beta$ ) once each month, and their averages and standard deviations were calculated using the $\chi^{2}$ test.The probability of $W_{3 \mathrm{~h}}$ for each month with respect to the time of the day $\left(P\left(W_{3 \mathrm{~h}}, t\right)\right)$ was calculated with the average values from 1970 through 2007. In this way, we obtained a probability matrix for each month:

$P_{\text {month }}\left(W_{3 \mathrm{~h}}, t\right)=\left(\begin{array}{ccc}p_{1,1} & \cdots & p_{1,8} \\ \vdots & \ddots & \vdots \\ p_{12,1} & \cdots & p_{12,8}\end{array}\right)$

being $\sum_{j=1}^{8} p_{k, j}=1 ; p_{k j}$ is the probability of $W_{3 \mathrm{~h}}$ range $k$ at time interval $j$.

\subsubsection{Wind simulation}

A monthly $W_{3 \mathrm{~h}}$ series must be generated to compute an accurate value for the water that will be pumped into the tank. We applied a monthly Weibull probability distribution in which the functions are used to generate independent and identically distributed random numbers. Once the $W_{3 \mathrm{~h}}$ is generated, it is classified within one of 12 ranges, and then the original data is divided. Lastly, the interval time $W_{3 \mathrm{~h}}$ is classified within a range. It should be located on the basis of the $P\left(W_{3 \mathrm{~h}}, t\right)$ from that month because we cannot use any autoregressive models due to lack of pertinent information from the original data.

Fifty simulations were performed for the data for each month to obtain a mean $W_{3 \mathrm{~h}}$ series and the frequencies for the 12 ranges. To validate the simulation algorithm, the volume of water that was pumped between the simulated frequencies and the real frequencies that were pumped at six wind velocities ranges (between 2.5 and $10.8 \mathrm{~m} / \mathrm{s}$ ) were compared with a $\chi^{2}$ test using the 2008 data.

The average values of the Weibull distributions ( $\alpha$ and $\beta$ ) were used for a simulation of an 'average wind year', and for the 'low wind year,' we used parameters $\left(\alpha-\sigma_{\alpha}\right)$ and $\left(\beta-\sigma_{\beta}\right)$. This scenario was simulated to assess specific situations in which the supply of water was expected to be sufficient, even under less than ideal conditions.

\subsection{Calculation of the flow extracted by the wind-pumps}

The flow data for different wind velocities and different elevation heights were taken from the manufacturer's literature for the wind pump. These values were plotted to empirically estimate the relationship between flow and wind velocity for each given elevation height with a determination coefficient error of \pm 0.01 . The flow that was extracted by the chosen wind pump was calculated with the following equations $(H$ : elevation height, $\mathrm{m}$; $\mathrm{Q}$ : water flow, $1 / \mathrm{min} ; W$ : wind velocity, $\mathrm{m} / \mathrm{s})$ :

$$
\begin{aligned}
& Q(H=15 \mathrm{~m}, W)=16.00 \cdot \ln W-13.47 \\
& Q(H=20 \mathrm{~m}, W)=9.13 \cdot \ln W-7.34 \\
& Q(H=25 \mathrm{~m}, W)=7.31 \cdot \ln W-6.08
\end{aligned}
$$

$H$ is defined as the difference in height between the free level of water in the well and the end of the tube that is depositing water into the tank.

In the present work, the empirical equations that are described above were used to calculate the flow that was extracted by the pumps for each $W_{3} \mathrm{~h}$. These values belong to a certain range $(2.77-10.8 \mathrm{~m} / \mathrm{s})$ and were used to estimate $Q$, which was recorded to obtain the daily and monthly flow that was extracted for each type of wind year (i.e., with low wind velocities or average wind velocities).

\subsection{Determination of crop water needs}

Greenhouse plants are subjected to partially controlled environmental conditions that are different from the outside conditions. Therefore, their water requirements are also different. Under greenhouse conditions, evapotranspiration (ETr) is significantly reduced; greenhouse agriculture therefore offers a way to reduce crop water consumption and, as a consequence, decreases the energy needed for pressure irrigation. The ETr has been determined from the direct evaporation of water in Piche evaporimeters and modified evaporation trays (Kirda et al., 1988; Yuan et al., 2001) and by using models such as the Penman Monteith or Priestley Taylor, both of which are widely accepted (Zhang and Lemeur, 1992; Ortega-Farias et al., 2004).

In the present work, the ETr of the greenhouse tomato crop was determined by using the methodology of León et al. (2005). These authors examined greenhouse-raised tomatoes on two planting dates (April 1996 and January 1997) in Cuba in the Province of Havana $\left(220^{\circ} 27.6^{\prime} \mathrm{N}, 820^{\circ} 22.2^{\prime} \mathrm{W}\right.$; altitude $\left.6 \mathrm{~m}\right)$. In this methodology, $E T r$ was calculated from the water balance in a compensation lysimeter that was located at the centre of the greenhouse. The crop coefficient for each growth stage was calculating following a similar approach to that of Doorembos and Pruitt (1977):

$E T r=K \cdot E T_{A}$

where $E \operatorname{Tr}$ is the real evapotranspiration of the studied crop ( $\mathrm{mm} /$ day), $E T_{A}$ is the evapotranspiration of the lysimeter ( $\mathrm{mm} /$ day) and $K$ is the proportionality crop coefficient (adimensional). A class A evaporimeter was used for the calculation of the $E T_{A}$.

León et al. (2005) showed that the partial isolation of a tomato crop inside a tunnel alters the crop environment. This effect is reflected by the evaporation behaviour, which was reduced by $43 \%$ in comparison to the outdoors in April and was further reduced by $45 \%$ in January. These results are similar to those reported by Castilla and Fereres (1990) and Fernández et al. (1994). León et al. (2005) recommended that $E T r$ and $K$ values shown in Table 1 should 
Table 1

Real evapotranspiration (ETr) and proportionality constant (K) values as described by León et al. (2005).

\begin{tabular}{|c|c|c|c|c|c|c|}
\hline \multirow[t]{2}{*}{ Growth phase } & \multicolumn{3}{|c|}{$\begin{array}{l}\text { Planting April-June } 1996 \\
\text { Tomato variety = Lignon }\end{array}$} & \multicolumn{3}{|c|}{$\begin{array}{l}\text { Planting January-May } 1997 \\
\text { Tomato variety FL-5 }\end{array}$} \\
\hline & Phase time (days) & $\operatorname{ETr}(\mathrm{mm} /$ day $)$ & $K$ & Phase time (days) & $\operatorname{ETr}(\mathrm{mm} /$ day $)$ & $K$ \\
\hline Vegetative development & 28 & 1.12 & 0.41 & 33 & 1.77 & 0.54 \\
\hline Flowering & 24 & 2.47 & 0.90 & 25 & 2.82 & 0.98 \\
\hline Fruiting & 21 & 2.61 & 0.99 & 23 & 3.30 & 1.08 \\
\hline Crop ripening & 18 & 1.91 & 0.55 & 32 & 2.80 & 0.78 \\
\hline Cycle mean & 91 & 1.98 & 0.71 & 113 & 2.60 & 0.85 \\
\hline
\end{tabular}

be used to estimate the irrigation needs of tomato crops that were grown in greenhouses with similar soil and climatic environments to those from their work.

\subsection{Maximum irrigable area}

The maximum area that can be irrigated by each type of wind pump in each type of wind year and for different elevation heights, tank volumes and planting dates was calculated by analysing the cumulative daily water balance, assuming that the water storage $\operatorname{tank}\left(W S T_{0}\right)$ is full at the beginning of the season $\left(W S T_{0}=\operatorname{tank}\right.$ volume):

$\mathrm{WST}_{i}=\mathrm{WST}_{i-1}-\mathrm{Dr}_{i}+V d_{i}$

where $D r_{i}$ is the required water for irrigation $\left(\mathrm{m}^{3}\right)$ at day $i, V d_{i}$ is the volume of water pumped $\left(\mathrm{m}^{3}\right)$ at day $i$, and $W S T_{i-1}$ is the water storage in the tank from the previous day.

$D r_{i}=10 \cdot A \cdot E T_{i}$

$V d_{i}=\sum_{j=1}^{8} 0.18 \cdot Q_{i, j}\left(H, W_{3 h i, j}\right)$

where $A$ is the area to irrigate (ha), ETr $r_{i}$ is the real evapotranspiration ( $\mathrm{mm} /$ day) at day $i, Q_{i, j}$, is the volume pumped into the tank $(1 / \mathrm{min})$ at day $i$ for every $3 \mathrm{~h}(\mathrm{j}), \mathrm{H}$ is elevation height $(\mathrm{m})$ and $W_{3 \mathrm{~h}}$ is the simulated wind velocity $(\mathrm{m} / \mathrm{s})$ at day $i$ for every $3 \mathrm{~h}(j)$.

The bulk irrigation dose $(\mathrm{Hb})$ was obtained from the irrigation efficiency $(E f)$ and the deficit coefficient $(C d)$, assuming a value of 0.85 for the drip irrigation system and its mode of management $(E f /(1-C d))$.

To determine the irrigable area, the following factors were taken into account:

- The annual wind characteristics.

The 3-h series were simulated for both an 'average wind year' and a 'low wind year'.

- Tank volume

The maximum irrigated area was determined with respect to the tank volume for a given reliability level to meet the ETr requirements.

- Planting date

Five different planting date variants were taken into account (Table 2) to assess the interactions between periods of high wind supply and low irrigation needs. The duration of the growth cycle and each of its phases remained constant given the scant variation in temperature and the hours of daylight during the analysis period.

\section{Results and discussion}

\subsection{Wind velocity study}

Fig. 2 shows the mean monthly wind velocities $(\bar{W})$ and their standard deviations $\left(\sigma_{W}\right)$ for the time period from 1970 to 2008 ,
Table 2

Different planting dates and the duration of the different tomato growth phases (variety FL-5).

\begin{tabular}{ll}
\hline Planting dates & Growth phase \\
\hline & $1: 10$ October-11 November \\
Variant 1 & $2: 12$ November-6 December \\
10th October & $3: 7$ December-29 December \\
& $4: 30$ December-30 January \\
& $1: 10$ November-12 December \\
Variant 2 & $2: 13$ December-6 January \\
10th November & $3: 7$ January-29 January \\
& $4: 30$ January-2 March \\
& $1: 10$ December-11 January \\
Variant 3 & $2: 12$ January-5 February \\
10th December & $3: 6$ February-28 February \\
& $4: 1$ March-1 April \\
& $1: 10$ January-11 February \\
Variant 4 & $2: 12$ February- 8 March \\
10th January & $3: 9$ March- 31 March \\
& $4: 1$ April-2 May \\
Variant 5 & $1: 10$ February-14 March \\
10th February & $2: 15$ March- 8 April \\
& $3: 9$ April-1 May \\
\hline
\end{tabular}

as well as the mean monthly values for 2008 . The results show the irregularity of wind velocities over the course of the year. Over these 39 years, March was the month with the highest $\bar{W}(3.41 \mathrm{~m} / \mathrm{s})$. The period with the highest wind velocities lasts from November to April, i.e., the dry season in Cuba (when only approximately $20 \%$ of the annual rainfall is received). The mean wind velocity for this period was $3.19 \mathrm{~m} / \mathrm{s}$. Therefore, the dry season was determined to be the best time to take advantage of wind energy for pumping water to guarantee that the water needs of the tomato crop in Cuba are met.

Table 3 shows that the values for $\alpha$ and $\beta$ were obtained by applying the Weibull II function for each month of the year based on a 38-year database with each month's respective standard deviations. We observed that some months (March, April and May) show a variation in their wind behaviour because some years can have $\alpha>1$ while others can have $\alpha \leq 1$, indicating in the former case an exponential shape and a reduction in the $W_{3 \mathrm{~h}}$ mean in the case of the former. The variation that was found for years that fell within the $\beta$ parameter was much lower and the behaviour of the Weibull

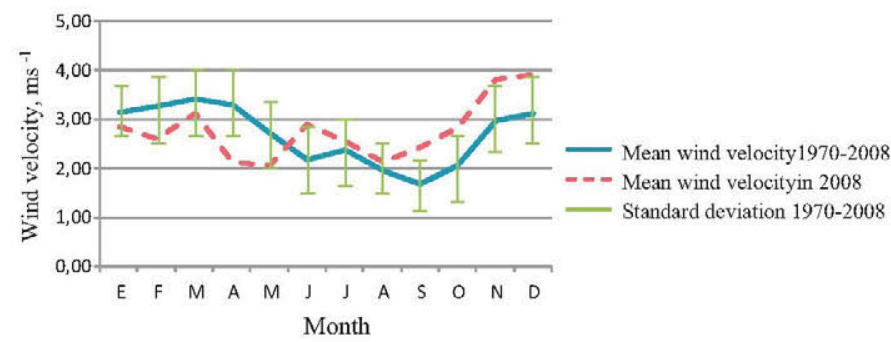

Fig. 2. Mean monthly wind velocity $(\mathrm{m} / \mathrm{s})$ for 2008 and mean monthly wind velocity and standard deviation for the period 1970-2008. 
Table 3

Shape $(\alpha)$ and scale $(\beta)$ factors mean values, with their standard deviations, for the construction of the monthly Weibull-II distribution for the months involved in the different planting date variants.

\begin{tabular}{lll}
\hline Month & $\alpha \pm \sigma_{\alpha}$ & $\beta \pm \sigma_{\beta}(\mathrm{m} / \mathrm{s})$ \\
\hline October & $1.16 \pm 0.10$ & $3.35 \pm 0.27$ \\
November & $1.20 \pm 0.08$ & $3.37 \pm 0.10$ \\
December & $1.33 \pm 0.10$ & $3.41 \pm 0.17$ \\
January & $1.33 \pm 0.05$ & $3.40 \pm 0.20$ \\
February & $1.15 \pm 0.08$ & $3.95 \pm 0.21$ \\
March & $1.09 \pm 0.14$ & $4.34 \pm 0.26$ \\
April & $0.96 \pm 0.17$ & $4.46 \pm 0.25$ \\
May & $0.88 \pm 0.12$ & $3.99 \pm 0.23$ \\
June & $0.89 \pm 0.10$ & $3.65 \pm 0.17$ \\
\hline
\end{tabular}

function was less affected than with the shape factor. Based on this result, we decided to simulate a 'low wind year' with a shape factor of $\left(\alpha-\sigma_{\alpha}\right)$ and a scale factor of $\left(\beta-\sigma_{\beta}\right)$.

An example of the frequency distribution that was obtained as a mean of 50 simulations for December in an 'average wind year' is shown in Fig. 3. We can observe that the $P\left(W_{3 h}, t\right)$ presents partial evidence that the highest velocities are more probable in the middle of the day rather than at the beginning or the end of the day.

Finally, the $W_{3 \mathrm{~h}}$ data were simulated for 2008 , and the wind frequency distribution (Fs) was shown within the range of wind velocities over which the functional pumps are compared with the real ones (see Table 4) in case of an 'average wind year'. A good
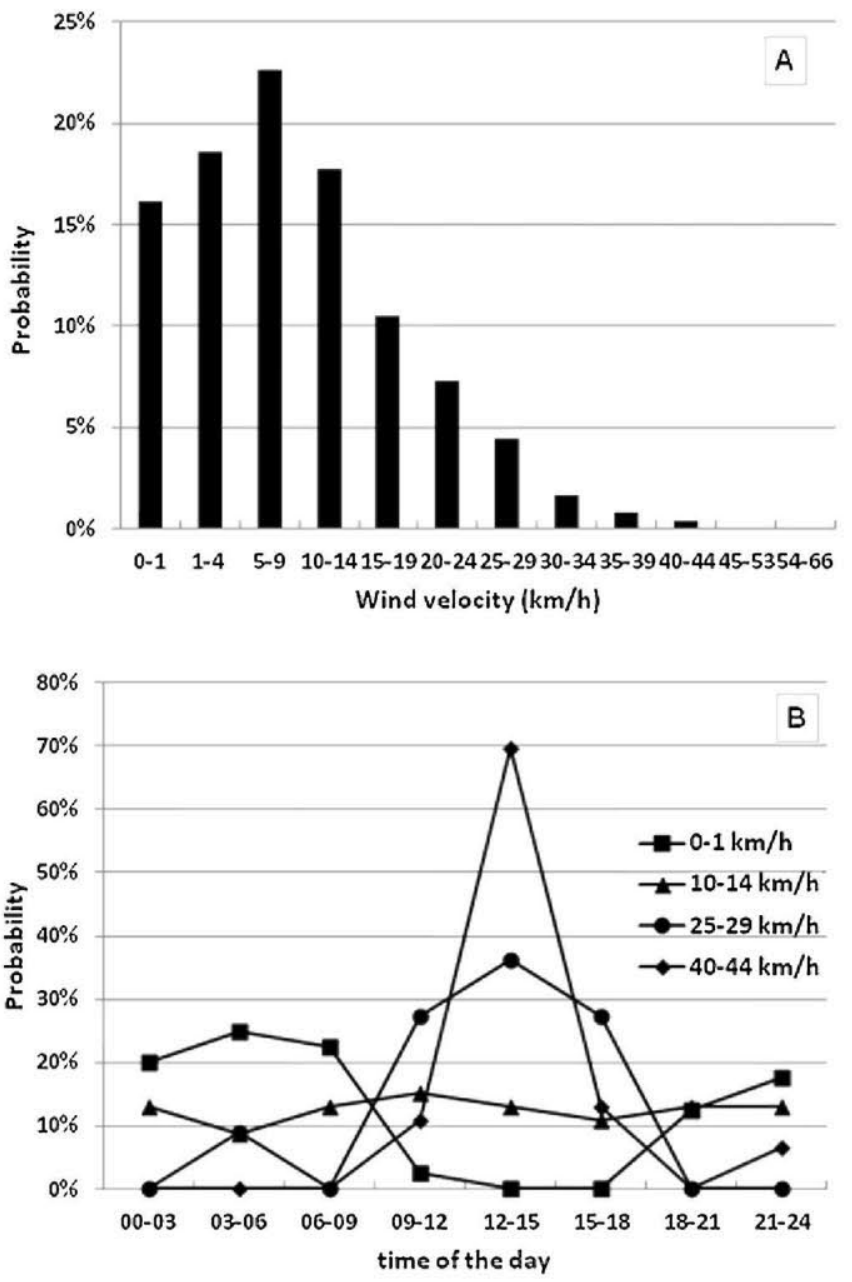

Fig. 3. Mean of 50 simulations of three-hourly wind velocities in December $(A)$. Part of the probability matrix $\left(P\left(W_{3 h}, t\right)\right)$ at different times of the day applied in the simulations (B).
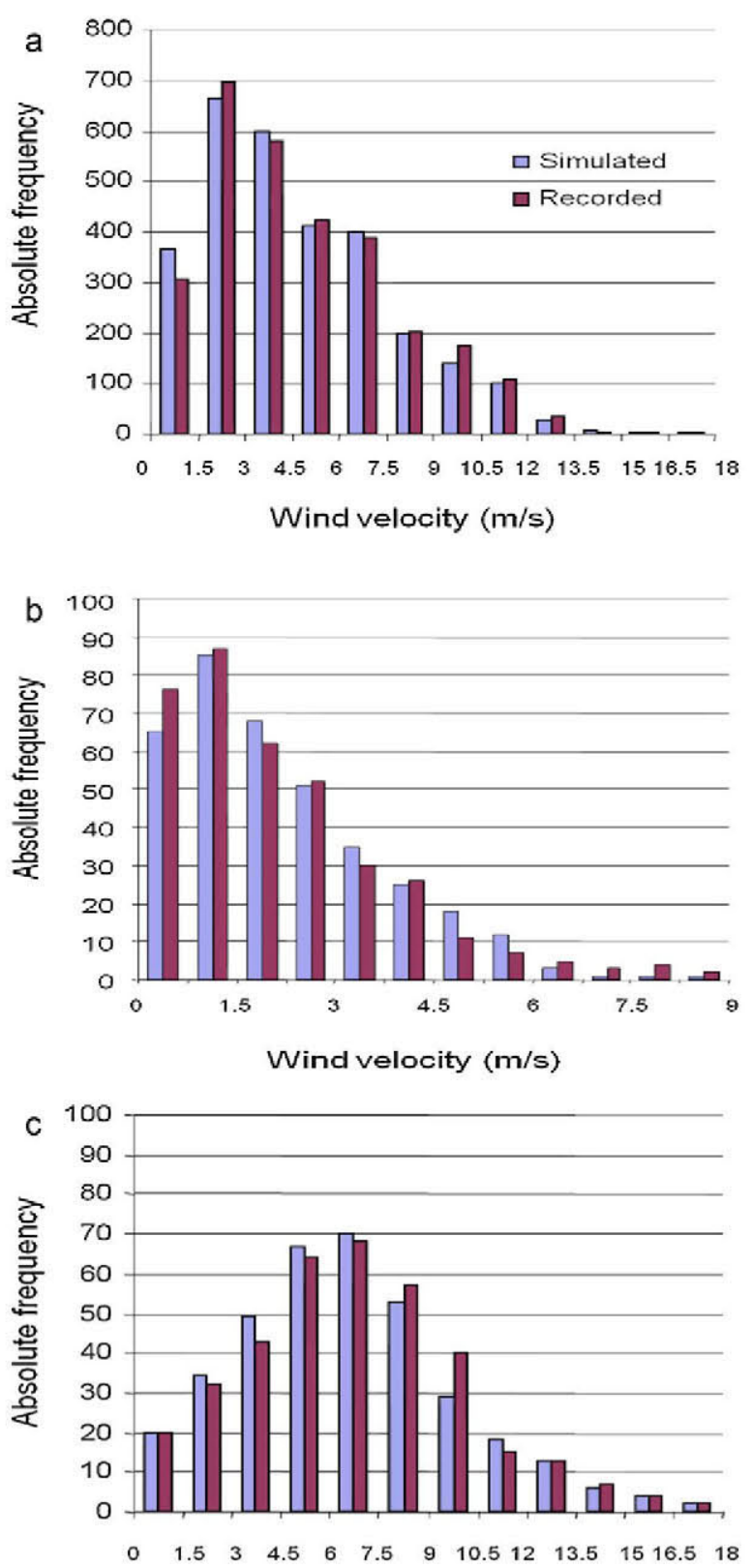

Wind velocity $(\mathrm{m} / \mathrm{s})$

Fig.4. Three-hourly wind velocity frequencies simulated and recorded in 2008 year: (A) all the time intervals, (B) at 6-9 h interval and (C) at 12-15 h.

convergence was noted between the simulated and recorded values, with a mean square error less than $3.5 \%$.

At the same time, Fig. 4 shows the distribution function of 3-h wind velocities that were measured during 2008, and the corresponding simulated values showed a patent similarity. These results highlight that the methodology described here can generate $W_{3 \mathrm{~h}}$ values with an acceptable error and a density function similar to that which was actually recorded.

\subsection{Water flow produced by the pumps}

Water was assumed to come directly from the ground aquifer via a well. Such an assumption is acceptable given the depth of the water table in the study area. Fig. 5 shows the mean, absolute minimum and absolute maximum water table depths for the area from 1990 to 2005. 
Table 4

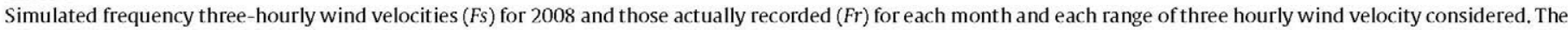
$\chi^{2}$ test has been evaluated for each month.

\begin{tabular}{|c|c|c|c|c|c|c|c|c|c|c|c|c|c|c|c|c|}
\hline \multirow[t]{2}{*}{ Wind velocity $(\mathrm{m} / \mathrm{s})$} & \multicolumn{2}{|c|}{ Ocotober } & \multicolumn{2}{|c|}{ November } & \multicolumn{2}{|c|}{ December } & \multicolumn{2}{|c|}{ January } & \multicolumn{2}{|c|}{ February } & \multicolumn{2}{|c|}{ March } & \multicolumn{2}{|c|}{ April } & \multicolumn{2}{|c|}{ May } \\
\hline & $\mathrm{Fr}$ & Fs & $\mathrm{Fr}$ & Fs & $\mathrm{Fr}$ & Fs & $\mathrm{Fr}$ & Fs & $\mathrm{Fr}$ & Fs & $\mathrm{Fr}$ & Fs & $\mathrm{Fr}$ & Fs & Fr & Fs \\
\hline $2.5-3.9$ & 39 & 36 & 42 & 41 & 44 & 42 & 41 & 39 & 39 & 38 & 43 & 39 & 34 & 32 & 33 & 32 \\
\hline $3.9-5.3$ & 24 & 25 & 21 & 21 & 26 & 26 & 27 & 27 & 25 & 25 & 26 & 24 & 26 & 24 & 26 & 24 \\
\hline $5.3-6.7$ & 18 & 17 & 17 & 17 & 18 & 17 & 21 & 20 & 19 & 19 & 25 & 25 & 22 & 22 & 20 & 22 \\
\hline $6.7-8.1$ & 8 & 8 & 8 & 8 & 11 & 11 & 10 & 10 & 11 & 11 & 12 & 12 & 11 & 11 & 9 & 10 \\
\hline $8.1-9.4$ & 7 & 6 & 4 & 4 & 4 & 5 & 5 & 5 & 6 & 6 & 9 & 8 & 7 & 6 & 7 & 6 \\
\hline $9.4-10.8$ & 2 & 2 & 1 & 1 & 2 & 2 & 3 & 3 & 2 & 2 & 4 & 4 & 2 & 3 & 3 & 3 \\
\hline Total & 98 & 94 & 93 & 92 & 105 & 103 & 107 & 104 & 102 & 101 & 119 & 112 & 102 & 98 & 98 & 97 \\
\hline$\chi^{2}$ test & \multicolumn{2}{|c|}{0.99} & \multicolumn{2}{|c|}{1.00} & \multicolumn{2}{|c|}{1.00} & \multicolumn{2}{|c|}{1.00} & \multicolumn{2}{|c|}{1.00} & \multicolumn{2}{|c|}{0.99} & \multicolumn{2}{|c|}{0.97} & \multicolumn{2}{|r|}{0.99} \\
\hline
\end{tabular}

Table 5

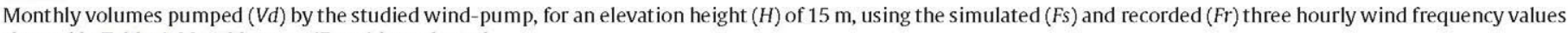
showed in Table 4. Monthly error (Error) is evaluated.

\begin{tabular}{|c|c|c|c|c|c|c|c|c|c|c|c|c|c|c|c|c|}
\hline \multirow[t]{2}{*}{ Wind velocity } & \multicolumn{2}{|c|}{ Ocotober } & \multicolumn{2}{|c|}{ November } & \multicolumn{2}{|c|}{ December } & \multicolumn{2}{|c|}{ January } & \multicolumn{2}{|c|}{ February } & \multicolumn{2}{|l|}{ March } & \multicolumn{2}{|l|}{ April } & \multicolumn{2}{|l|}{ May } \\
\hline & $\mathrm{Fr}$ & Fs & $\mathrm{Fr}$ & FS & $\mathrm{Fr}$ & Fs & $\mathrm{Fr}$ & Fs & $F r$ & $F S$ & $\mathrm{Fr}$ & Fs & $F r$ & Fs & Fr & Fs \\
\hline $2.5-3.9$ & 36.1 & 33.3 & 38.9 & 37.9 & 40.7 & 38.9 & 37.9 & 36.1 & 36.1 & 35.2 & 39.8 & 36.1 & 31.5 & 29.6 & 30.5 & 29.6 \\
\hline $3.9-5.3$ & 47.3 & 49.3 & 41.4 & 41.4 & 51.2 & 51.2 & 53.2 & 53.2 & 49.3 & 49.3 & 51.2 & 47.3 & 51.2 & 47.3 & 51.2 & 47.3 \\
\hline $5.3-6.7$ & 49.2 & 46.5 & 46.5 & 46.5 & 49.2 & 46.5 & 57.4 & 54.7 & 52.0 & 52.0 & 68.4 & 68.4 & 60.2 & 60.2 & 54.7 & 60.2 \\
\hline $6.7-8.1$ & 26.7 & 26.7 & 26.7 & 26.7 & 36.7 & 36.7 & 33.4 & 33.4 & 36.7 & 36.7 & 40.1 & 40.1 & 36.7 & 36.7 & 30.1 & 33.4 \\
\hline $8.1-9.4$ & 26.8 & 22.9 & 15.3 & 15.3 & 15.3 & 19.1 & 19.1 & 19.1 & 22.9 & 22.9 & 34.4 & 30.6 & 26.8 & 22.9 & 26.8 & 22.9 \\
\hline $9.4-10.8$ & 8.5 & 8.5 & 4.2 & 4.2 & 8.5 & 8.5 & 12.7 & 12.7 & 8.5 & 8.5 & 16.9 & 16.9 & 8.5 & 12.7 & 12.7 & 12.7 \\
\hline$V d\left(\mathrm{~m}^{3}\right)$ & 194.6 & 187.2 & 173.0 & 173.01 & 201.7 & 200.9 & 213.8 & 209.52 & 205.5 & 204.5 & 250.8 & 239.4 & 214.8 & 209.5 & 206.0 & 206.1 \\
\hline Error & \multicolumn{2}{|c|}{$-3.8 \%$} & \multicolumn{2}{|c|}{$-0.5 \%$} & \multicolumn{2}{|c|}{$-0.4 \%$} & \multicolumn{2}{|c|}{$-2.1 \%$} & \multicolumn{2}{|c|}{$-0.5 \%$} & \multicolumn{2}{|c|}{$-4.6 \%$} & \multicolumn{2}{|c|}{$-2.5 \%$} & \multicolumn{2}{|c|}{$0.1 \%$} \\
\hline
\end{tabular}

Table 5 shows the volumes that were pumped by the study wind pump, where $H=15 \mathrm{~m}$ using the simulated and recorded $W_{3 \mathrm{~h}}$ values. The monthly volumes of water that were extracted by the wind pump $(V d)$ were then compared, giving a maximum sub-estimation error of approximately $4 \%$ in March and October.

\subsection{Crop water requirements}

The daily evapotranspiration values for each phase of the growth cycle of greenhouse-raised tomatoes (variety FL-5) accounted for the planting date, and these values are shown in Table 6 .

Planting date variants 1 and 2 were associated with the lowest daily ETr; and these planting dates are associated with less crop water consumption.

\subsection{Maximum irrigable area}

Fig. 6 and Table 7 show the area that can be irrigated (Ar) with respect to the planting date and the monthly volume of water that

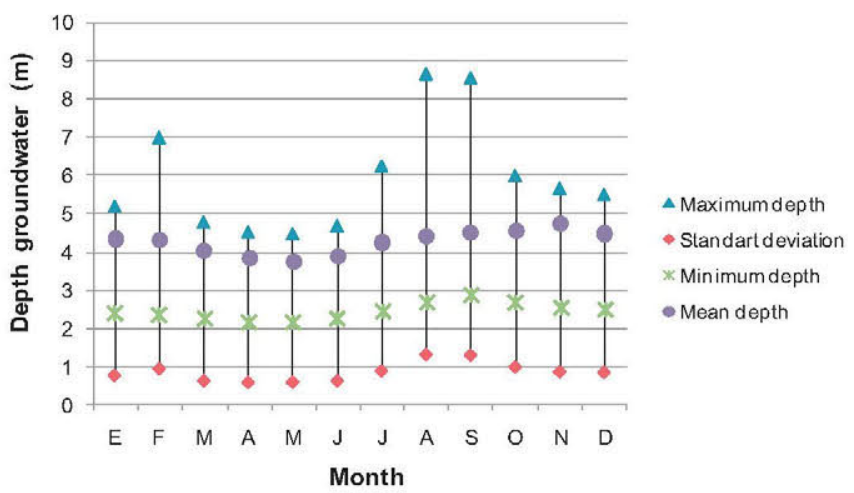

Fig. 5. Water table depths recorded, from 1990 till 1995, for hydrological sector CA-II-2 (wells 814 and 9795), Province of Ciego de Ávila (Cuba).

Source: Instituto Nacional de Recursos Hidráulicos de Cuba (INRH). is available $(V d)$ for a year of average wind velocities that were determined using 3-h data. It is assumed at this step that the water tank can accept all the water that is pumped into it during a period of one month; the influence of the tank volume will be studied later.

The results shown here are from the month in which flowering occurred, i.e., when water needs were at their greatest (see Table 6). For all planting date variants, the mean wind velocity at the time of greatest water need was above the starting wind velocities that were required by the different pumps.

Analysis of the data presented in the above-mentioned table and figure reveals that planting date variants 1 and 2 are the best with respect to irrigable area. Variant 2 is associated with the greatest

Table 6

Real crop evapotranspiration (ETr $)$ values in $\mathrm{mm} / \mathrm{month}$ and $\mathrm{mm} /$ day for each plant ing date variant and growth phase cycle.

\begin{tabular}{llll}
\hline Planting date & Growth phase & ETr \\
\cline { 3 - 4 } & & $(\mathrm{mm} / \mathrm{month})$ & $(\mathrm{mm} /$ day $)$ \\
\hline \multirow{3}{*}{1} & 1 & 30.49 & 0.92 \\
& 2 & 38.74 & 1.55 \\
& 3 & 39.71 & 1.73 \\
& 4 & 41.44 & 1.30 \\
2 & 1 & 28.24 & 0.86 \\
& 2 & 39.56 & 1.58 \\
& 3 & 41.34 & 1.80 \\
& 4 & 53.52 & 1.67 \\
& 1 & 28.88 & 0.88 \\
& 2 & 43.16 & 1.73 \\
& 3 & 53.42 & 2.32 \\
4 & 4 & 63.77 & 1.99 \\
& 1 & 32.55 & 0.99 \\
& 2 & 55.76 & 2.23 \\
& 3 & 63.17 & 2.75 \\
5 & 4 & 72.65 & 2.27 \\
& 1 & 41.29 & 1.25 \\
& 2 & 64.92 & 2.60 \\
& 3 & 72.40 & 3.15 \\
& 4 & 67.25 & 2.10 \\
\hline
\end{tabular}


Table 7

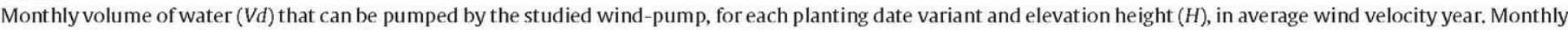

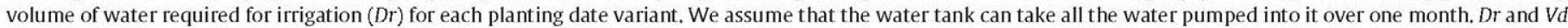
are calculated in the most unfavourable month of the planting date variant: the month with higher irrigation needs in relationship with the volume that can be pumped.

\begin{tabular}{|c|c|c|c|c|c|c|}
\hline \multirow[t]{2}{*}{ Planting date variant } & \multirow[t]{2}{*}{ Month } & \multirow[t]{2}{*}{$E \operatorname{Tr}(\mathrm{mm} /$ day $)$} & \multirow[t]{2}{*}{$\operatorname{Dr}\left(\mathrm{m}^{3} /\right.$ ha month $)$} & \multicolumn{3}{|c|}{$\begin{array}{l}V d\left(\mathrm{~m}^{3} / \text { month }\right) \\
H\end{array}$} \\
\hline & & & & $15 \mathrm{~m}$ & $20 \mathrm{~m}$ & $25 \mathrm{~m}$ \\
\hline 1 & December & 1.67 & 609.1 & 184.89 & 112.97 & 86.25 \\
\hline 2 & January & 1.75 & 638.2 & 208.45 & 126.68 & 97.06 \\
\hline 3 & February & 2.17 & 714.8 & 206.81 & 125.33 & 96.24 \\
\hline 4 & March & 2.62 & 955.5 & 251.89 & 151.99 & 117.06 \\
\hline 5 & April & 3.00 & 1058.8 & 200.02 & 121.31 & 93.10 \\
\hline
\end{tabular}

inter-annual mean wind velocities (1970-2008 data), with a mean of $3.18 \mathrm{~m} / \mathrm{s}$ for the growing cycle in comparison to just $2.90 \mathrm{~m} / \mathrm{s}$ for variant 1 . Thus, variant 2 is associated with fewer wind velocity values below the starting velocity of the pumps and is therefore the best planting date variant.

During the month of maximum water demand for the planting date of variant 2 , the wind pump could irrigate 0.33 ha, 0.20 ha and 0.15 ha for elevation heights of $15 \mathrm{~m}, 20 \mathrm{~m}$ and $25 \mathrm{~m}$, respectively. Compared to planting date variant 2 , variant 5 was associated with a reduction in the irrigable area by $40-45 \%$ for the wind pump in this study. With respect to the elevation height, when comparing $H=15 \mathrm{~m}$ with $H=25 \mathrm{~mm}$, the taller height was associated with a reduction in irrigable area of $52-55 \%$ for the wind pump (Fig. 6). Higher tank elevations are related to lower costs for the pipes and fittings in the water distribution network that feeds the drip irrigation units. Therefore, determining the tank elevation is a minimisation problem regarding the investment needed for irrigating the greenhouse area.

\subsection{Storage tank volume}

With respect to the water tank volume, Fig. 7 shows the maximum irrigable areas for planting date variant 2 for a year of average mean wind velocities and a year of low mean wind velocities, assuming an elevation height of $15 \mathrm{~m}$. These data were obtained from the cumulative water demand and accumulated volume of water for the entire irrigation period, assuming that the water tank

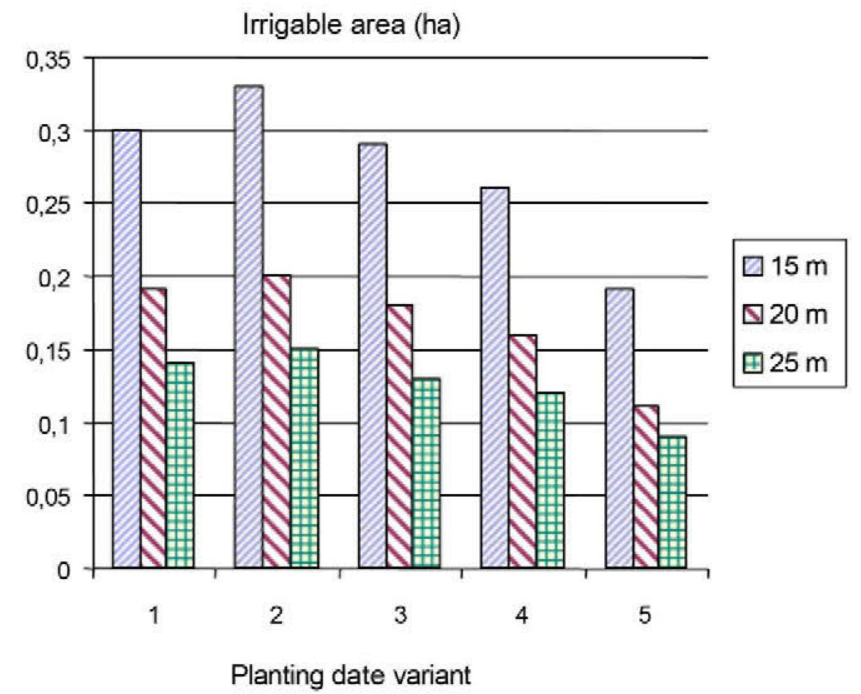

Fig. 6. Maximum irrigable area, by wind-pump, estimated for each planting date variant in an 'average wind year'. Three elevation heights $(H)$ have been considered: 15,20 and $25 \mathrm{~m}$. We assume that the water tank can take all the water pumped into it over one month. could store all the water that was pumped into it from April 1st to November 9th.

The figure shows that the area that can be irrigated will vary depending on the volume of the water tank. If the tank was very small, the irrigable area would be smaller than that which is shown in Table 7 because windy periods are interspersed with periods of calm, and the water in the tank could not meet the water requirements of the crop on calm days. In contrast, if the tank was large, water collected in one month could be used to cover the deficits of another month, and the irrigable area would be higher than that shown in the previous tables.

The storage volume is related to the reliability level of the water supply. In the worst case scenario (a low wind velocity year, irrigation guarantee of $84 \%$ and $H=15 \mathrm{~m}$ ), a storage tank of $25 \mathrm{~m}^{3}$ could irrigate 0.27 ha (data in Fig. 6). Under the same conditions with the exception of a $5 \mathrm{~m}^{3}$ storage tank, 0.21 ha could be irrigated with the wind pump (a $22 \%$ reduction from when a $25 \mathrm{~m}^{3}$ tank is available). It is worth highlighting that the first $5 \mathrm{~m}^{3}$ storage tank allows the irrigation of $0.21 \mathrm{ha}$; an addition of $20 \mathrm{~m}^{3}$ only allows for the irrigation of $0.06 \mathrm{ha}$. Therefore, this factor causes smaller variations in the irrigation area than the planting date or elevation height, as shown in Fig. 6 , once a minimal storage volume value is reached.

The optimum water tank size could be determined via an economic analysis, taking into account the income generated and the total costs associated with each size option. The total costs would include the fixed costs of investment in the wind pump and well, as well as the variable (size-dependent) costs of the water tank. The income would be calculated from production, the market price of the product, and the irrigated area.

The methodology described in the present work can determine the water reservoir size for a typical number of days of calm periods to use as basic data. A preliminary step includes the determination of the irrigable area, which considers the wind pump model and the elevation height on a monthly basis, as performed in the present study in Section 3.4. Afterwards, the number of days of calm periods multiplied by the mean daily water flow supplied by the wind pump

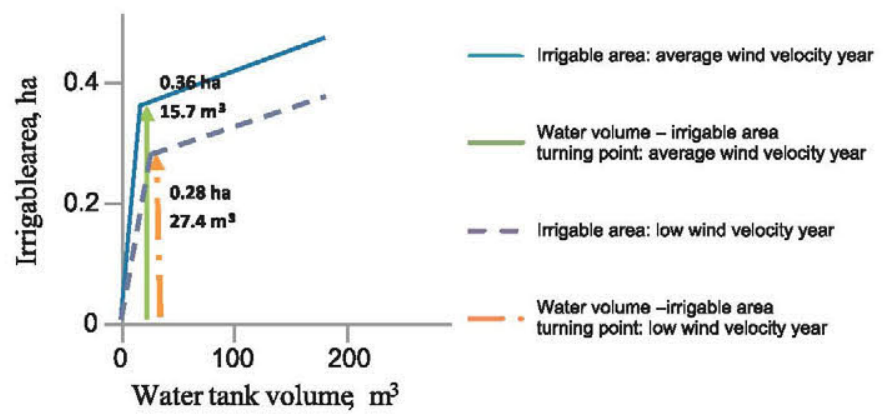

Fig. 7. Maximum irrigable area with the wind-pump for an 'average wind year' and 'low wind year'. Planting date is variant $\# 2$ and elevation height $(H)$ is $15 \mathrm{~m}$. 
in this period (considering the real elevation height of the period) determines the water volume that is lost during the calm periods. Assuming a scenario of a "low wind velocity year", this storage tank volume will supply an irrigation guarantee of $84 \%$.

Additionally, the calculated value of storage volume can be verified via economic analysis. In western Kansas, Hagen and Sharif (1981) undertook a long-term study on the relationships between monthly run-off, pumped monthly run-off, the pumping capacity of the wind pump, and the storage tank capacity. These authors concluded that different combinations of wind pump sizes and storage tank capacities could be used to pump a given volume, and the selection of the best combination for each site would be decided via an economic analysis.

In comparing the different factors, the planting date has been a key factor in maximising the irrigable area as well as maximising the potential of the water pumping system. A planting delay of three months can approximately double the irrigable area. When energy is not a limiting factor, the planting date should be decided depending on market factors, including the price the product can bring. However, because Cuba has severe restrictions in terms of both energy and food availability, the advantages that might be obtained from the choice of planting date may be important when deciding on the growing calendar.

According to the present results, the elevation height has also a decisive influence on the irrigable area. Decreasing the elevation height from $25 \mathrm{~m}$ to $15 \mathrm{~m}$ can approximately double the irrigable area. Finally, the influence of the storage tank volume has been shown here; the methodology described in this article permits a reservoir volume recommendation. From a quantitative point of view, this factor has a smaller influence on the irrigation area than the planting date or elevation height.

\section{Conclusions}

1. A relatively simple methodology that seeks to balance the water needs with water availability was used to determine the potential of the wind to pump water, taking into account the characteristics of the wind pump and the local wind statistics. The planting date was studied as a factor in this work.

2. A method for generating 3-h wind velocities from monthly data was validated, with a mean square error that was lower than $3.5 \%$.

3. The results show that the factors that most influence the irrigable area of greenhouse tomato crops are the planting date and the tank elevation height. These factors can double the irrigation area through the delay of the planting date by three months or with reductions of the elevation height from $25 \mathrm{~m}$ to $15 \mathrm{~m}$.

4. The optimum period of wind pump-driven irrigation in Cuba for the cultivation of greenhouse tomatoes is from November to March, when the winds are stronger. It is recommended that a storage tank volume of $5 \mathrm{~m}^{3}$ be used for cultivated areas of approximately 0.2 ha when using wind pumps for elevations of $15 \mathrm{~m}$ with an irrigation water level reliability level of $84 \%$ for these specific areas in Cuba. The methodology could be extended to other situations and wind pump models as long as the head/flow curves are known with respect to the wind velocity.

\section{Acknowledgements}

First author work was supported by a grant awarded by the Spanish International Cooperation Agency (AECI). Also, funding provided by Spanish Ministerio de Ciencia e Innovación (MICINN) through projects nos. AGL2010-21501/AGR and AGL2008-00153/AGR is greatly appreciated.

\section{References}

Atsu, S.S., 2002. Estimating wind velocity distribution. Energy Conversion and Man agement 43, 2311-2318.

Baracca, Á., 2007. La insostenibilidad del pet róleo. Revista Energía y Tú 37, 25-26.

Castilla, N., Fereres, E., 1990. The climate and water requirements of tomatoes in unheated plastic greenhouses. Agricultura Mediterránea 120, 268-274.

Celik, 2003. Long-term energy output estimation for photovoltaic energy systems using synthetic solar irradiation data. Energy 28, $479-493$.

Corotis, R.B., Sigi, A.B., Klein, J., 1978. Probability models of wind velocity magnitude and persistence. Solar Energy 20, 483-493.

Corp, L., 2003. Energía e indicadores de desarrollo energético sostenible. Cubasolar, http://www.cubasolar.cu/biblioteca/energia/Energia24/HTML/Articulo10.htm

Doorembos, J., Pruitt, W. O., 1977. Crop water requirements. FAO Irrigation and Drainage Paper No. 24, FAO, Rome.

Fernández, M.D., Orgaz, J., López, J., 1994. La demanda evaporativa en el invernadero parral. Estación Experimental Las Palmerillas, Almería, España, pp. 1-9.

García, J.L., Navas, L.M., Benavente, R.M., Luna, L., Muñoz, M., 1999. Diferentes tipos de invernaderos. Vida Rural 88, 44-47.

González, P., Mendez, M., 2004. Panorama del riego y el drenaje en Cuba. Revista Ciencias Técnicas Agropecuarias 13 (2), 1-10.

Hagen, L.J., Sharif, M., 1981. Wind-powered irrigation tailwater system: sizing the wind turbine and storage pit. Transactions of the ASAE 24 (1), 103-112.

Henneessy, J.P., 1977. Some aspects of wind power statistics. Journal of Applied Meteorology 16, 119-128.

Kirda, C., Cevik, B., Tulucu, K., 1988. A simple method to estimate the irrigation water requirement of greenhouse grown tomato. Acta Horticulturae 366, 371-380.

León, M., Cun, R., Chaterlán, Y., Rodriguez, R., 2005. Uso eficiente del agua en el cultivo del tomate protegido. Resultados obtenidos en Cuba. Revista Ciencias Técnicas Agropecuarias 14 (3), 9-13.

Lun, I.Y.F., Lan, J.C., 2000. A study of Weibull parameters using long-term wind observations. Renewable Energy 20, 145-153.

Minagri, A., 2000. Inst ructivo técnico de casas de cultivo protegidos. Ministerio de la Agricultura, Centro Nacional de Sanidad Vegetal, Havana, Cuba, pp. 1-65.

Nova, A., 2007. La agricultura en Cuba. Evolucióny trayectoria(1959-2005). Editorial Ciencias Sociales, Havana, Cuba, pp. 1-22.

Nova, A., 2012. La agricultura cubana y el actual proceso de transformaciones económicas. Centro de Estudios de la Economía Cubana, University of Havana, Cuba, pp. 1-8.

Ortega-Farias, S.O., Rojas, V., Valdés, H., González, P., 2004. Estimation of reference evapotranspiration in the Maule Region of Chile: a comparison between the FAO Penman-Monteith and Bowen Ratio methods. Acta Horticulturae 664, 469-475.

Panda, R.K., Sarkar, T.K., Bhattacharya, A.K., 1990. Stochastic study of wind energy potential of India. Energy 15 (10), 921-930.

Proenza, J., Pérez, R., Díaz, E., Piña, J.E., 2007. Mapa del potencial eólico de la provincia de Holguín. Revista Ciencias Holguín 12 (3), 1-8.

Rehman, S., Halawani, T.O., Husain, T., 1994. Weibull parameters for wind speed distribution in Saudi Arabia. Solar Energy 53 (6), 473-479.

Sathyajith, M., Pandey, K.P., Anil Kumar, V., 2002. Analysis of wind regimes for energy estimation. Renewable Energy 25 (3), 381-399.

Scerri, E., Farrugia, R., 1996. Wind data evaluation in the Maltese Islands. Renewable Energy 7 (1), 109-114.

Stevens, M.J.M., Smulders, P.T., 1979. The estimation of parameters of the Weibull wind speed distribution for wind energy utilization purposes. Wind Engineering 3 (2), $132-145$.

Torres, J., 2007. La biomasa cañera y sus potencialidades. In: Proceedings from the Conferencia Cátedra Azucarera Álvaro Reynoso, University of Havana, Cuba, April.

Vázquez, C., Montesinos, L., 2007. Alimentación, energía y sostenibilidad. Revista Energía y Tú 39, 39-44.

Yuan, B., Kang, Y., Nishiyama, S., 2001. Drip irrigation scheduling for tomatoes in unheated greenhouses. Irrigation Science 20 (3), 149-154.

Zhang, L., Lemeur, R., 1992. Effect of aerodynamic resistance on energy balance and Penman-Monteith estimates of evapotranspiration in greenhouse conditions. Agricultural and Forest Meteorolology 58, 209-228. 